\title{
PENGARUH PENERAPAN ASYNCHRONOUS LEARNING DAN MOTIVASI BELAJAR TERHADAP HASIL BELAJAR
}

\author{
Siswanto ${ }^{1}$, M. Abdul Rohman Kartanagara ${ }^{1}$, dan Liu Su Chuan ${ }^{2}$ \\ ${ }^{1}$ Fakultas Ekonomi, Universitas Negeri Yogyakarta, Indonesia \\ ${ }^{2}$ Department of Marketing and Logistics Management Chaoyang University of Technology Taiwan \\ email: siswanto@uny.ac.id
}

\begin{abstract}
Abstrak
Penelitian ini bertujuan untuk mengetahui pengaruh penerapan Asynchronous Learning dan Motivasi Belajar terhadap Hasil Belajar Administrasi Pajak peserta didik kelas XII Akuntansi Sekolah Menengan Kejuruan. Penelitian ini merupakan penelitian ex-post-facto dengan pendekatan kuatitatif. Populasi dalam penelitian ini adalah seluruh siswa kelas XII Jurusan Akuntansi Keuangan dan Lembaga sejumlah 162 peserta didik dan jumlah sampel yang diambil sebanyak 64 siswa. Metode pengumpulan data menggunakan angket/kuesioner. Uji prasyarat analisis data meliputi uji Normalitas, linearitas, uji multikolinearitas, dan uji heteroskedastisitas. Teknik analisis data yang digunakan dalam penelitian ini adalah analisis regresi sederhana dan analisis regresi ganda. Hasil penelitian menunjukkan terdapat pengaruh positif dan signifikan antara penerapan Asynchronous learning terhadap hasil belajar administrasi pajak. Adanya pengaruh positif dan signifikan antara motivasi belajar terhadap hasil belajar administrasi pajak. Hasil penelitian juga menunjukkan pengaruh positif dan signifikan secara bersama-sama antara penerapan Asynchronous learning dan motivasi belajar terhadap terhadap hasil belajar administrasi pajak.
\end{abstract}

Kata kunci: asynchronous learning, motivasi belajar, hasil belajar

\section{THE EFFECT OF ASYNCHRONOUS LEARNING IMPLEMENTATION AND LEARNING MOTIVATION TOWARD LEARNING OUTCOMES}

\begin{abstract}
This study aimed to determine the effect of the application of Asynchronous Learning and Learning Motivation on Tax Administration Learning Outcomes for Class XII Accounting Vocational High School students. This research was an ex-post-facto research with a quantitative approach. The population in this study were all students of class XII of the Department of Financial Accounting and Institutions with a total of 162 students and the number of samples taken as many as 64 students. The data collection method used a questionnaire/questionnaire. Prerequisite tests of data analysis included normality, linearity, multicollinearity, and heteroscedasticity tests. The data analysis techniques used in this research were simple regression analysis and multiple regression analysis. The results showed that there was a positive and significant effect between the application of Asynchronous Learning on the learning outcomes of tax administration. There is a positive and significant influence between learning motivation on tax administration learning outcomes. The results also show a positive and significant effect jointly between the application of Asynchronous learning and learning motivation on the learning outcomes of tax administration

Keywords: asynchronous learning, learning motivation, learning outcomes
\end{abstract}




\section{PENDAHULUAN}

Pendidikan merupakan kebutuhan utama untuk membangun sebuah bangsa yang maju. Menurut UU Nomor 20 Tahun 20-03 tentang Sistem Pendidikan Nasional (SISDIKNAS) pendidikan didefinisikan sebagai berikut:

"Pendidikan adalah usaha sadar dan terencana untuk mewujudkan suasana belajar dan proses pembelajaran agar peserta didik secara aktif mengembangkan potensi dirinya untuk memiliki kekuatan spiritual keagamaan, pengendalian diri, kepribadian, kecerdasan, akhlak mulia, serta keterampilan yang diperlukan dirinya, masyarakat, bangsa, dan negara".

Keberadaan pendidikan adalah hal paling penting bagi seorang manusia (Alpian dkk., 2019). Penyelenggaraan pendidikan berkualitas dengan sistem pembelajaran efektif dapat menciptakan sumberdaya manusia kompeten dan berdaya saing tinggi di semua bidang (Muchlis dkk., 2018).

Salah satu bentuk pembelajaran yang memanfaatkan teknologi internet dalam bidang pendidikan adalah e-learning (Fauziyah \& Triyono, 2020). Berdasarkan data dari Pew Research Center yang (Tempo.co, 2018), saat ini di Indonesia pengguna smartphone yang mempunyai usia remaja berjumlah $66 \%$ dari jumlah populasi. Ini menandakan bahwa mayoritas pelajar di Indonesia siap untuk melakukan pembelajaran secara daring.

Tiurma dan Retnawati (2014) menjelaskan bahwa pembelajaran yang menggunakan multimedia dalam e-learning lebih efektif. Selain itu, dengan diterapkannya e-learning peserta didik dapat dengan mudah untuk mengakses setiap materi pembelajaran. Peserta didik bisa dengan mudah untuk mengulang-ulang materi yang belum dikuasai hingga bisa menguasainya.

Salah satu aspek keberhasilan pendidikan adalah pencapaian kompetensi dan materi pelajaran yang disampaikan oleh pendidik sesuai dengan tujuan pembelajaran (Falah, 2015). Ketercapaian ini dapat dilihat dari meningkatnya hasil belajar peserta didik. Hasil belajar merupakan perubahan tingkah laku yang terjadi dalam diri peserta didik yang mencangkup bidang kognitif, afektif, dan psikomotorik (Kunandar, 2014, p. 62). Ada beberapa faktor yang dapat mempengaruhi hasil belajar peserta didik, faktor tersebut adalah faktor internal dan faktor eksternal (Kurniawan dkk., 2017). Dalam penelitian ini peneliti memasukkan faktor eksternal (penerapan asynchronous learning) dan faktor internal (motivasi belajar) sebagai variabel yang diteliti dalam menentukan hasil belajar peserta didik.

Penyelenggaraan pendidikan di Indonesia terbagi ke dalam tiga jenjang yaitu, Sekolah Dasar (SD), Sekolah Menengah Pertama (SMP), dan Sekolah Menengah Atas (SMA)/Sekolah Menengah Kejuruan (SMK). Di masing-masing jenjang tersebut peserta didik diajarkan ilmu pengetahuan yang disesuaikan dengan tahap perkembangannya. Tarigan (2006, p. 24) menjelaskan bahwa jenjang yang paling berdampak pada kehidupan peserta didik adalah jenjang SMA/SMK. Oleh sebab itu, kita perlu memaksimalkan peran dari jenjang ini terutama jenjang SMK.

Undang-undang Nomor 20 Tahun 2003 pasal 15 menjelaskan bahwa "Pendidikan kejuruan merupakan pendidikan menengah yang mempersiapkan peserta didik untuk bekerja dalam bidang tertentu". Lebih lanjut dalam Peraturan Pemerintah Nomor 19 Tahun 2005 tentang Standar Pendidikan Nasional menyatakan bahwa Pendidikan Menengah Kejuruan merupakan pendidikan menengah yang mengutamakan 
pengembangan kemampuan siswa untuk jenis pekerjaan tertentu.

Berdasarkan data yang diperoleh dari laman puspendik.kemdikbud.go.id, SMK YPKK 2 Sleman sejak tahun 20172019 mengalami masalah mengenai hasil belajar peserta didik pada mata pelajaran kompetensi keahlian akuntansi. SMK YPKK 2 Sleman adalah sekolah yang berfokus pada bidang studi keahlian bisnis dan manajemen, dengan kompetensi keahlian akuntansi keuangan lembaga dan pemasaran.

Sejak Maret 2020, melalui Surat Edaran Nomor 4 Tahun 2020 tentang Pelaksanaan Kebijakan Pendidikan dalam masa darurat penyebaran Covid-19, pembelajaran di seluruh wilayah DIY mengalami perubahan. Pembelajaran semula yang dilaksanakan secara tatap muka berganti menjadi pembelajaran secara e-learning. Pembelajaran e-learning dapat diselenggarakan dengan dua cara, yakni dengan synchronous learning dan asynchronous learning (Pakpahan \& Fitriani, 2020).

Marie (2009) menyatakan bahwa synchronous learning adalah pembelajaran e-learning yang mengharuskan peserta didik dan guru hadir didalam satu ruang virtual dalam waktu yang bersamaan sedangkan asynchronous learning adalah e-learning yang tidak membutuhkan waktu secara bersamaan. Salah satu contoh penggunaan Synchronous learning adalah penggunaan video call pada aplikasi zoom, google meet, atau whatsapp. Lalu, contoh penggunaan asynchronous learning adalah platform Edmono, google classroom, dan be-smart.

Asynchronous learning menjadi model pembelajaran yang paling sering digunakan di SMK YPKK 2 Sleman. Setelah diselenggarakan sejak bulan Maret hingga Juni, hasil belajar peserta didik menunjukkan bahwa terdapat banyak peserta didik yang memperoleh nilai Penilain Akhir Semester (PAS) di bawah Kriteria Belajar Minimum (KBM). Hal ini dapat dilihat dari data yang diperoleh peneliti sebagai berikut 89,70\% (146 peserta didik) pada Mata Pelajaran Administrasi Pajak; 75,76\% (120 peserta didik) pada Komputer Akuntansi; 87,88\% (145 peserta didik) pada Praktik Akuntansi Perusahaan Dagang belum mencapai KBM yang telah ditetapkan yaitu 75. Dari ketiga mata pelajaran tersebut juga diperoleh informasi bahwa Administrasi Pajak merupakan mata pelajaran yang mempunyai paling banyak peserta didik yang gagal mencapai KBM.

Penerapan asynchronous learning juga membawa dampak lain dalam bidang psikologi yakni motivasi belajar peserta didik, selain berdampak pada hasil belajar peserta didik. Motivasi dapat diartikan sebagai kekuatan, dorongan, kebutuhan, semangat, tekanan, atau mekanisme psikologis yang mendorong seseorang atau kelompok untuk mencapai prestasi tertentu sesuai yang dikehendaki (Suprihatin, 2015). Peserta didik dengan motivasi belajar yang tinggi cenderung memperoleh hasil belajar yang lebih baik dibandingkan peserta didik yang mempunyai motivasi belajar yang rendah. Oleh karena itu, keberadaan motivasi belajar adalah kunci keberhasilan dalam mencapai tujuan pembelajaran (Emda, 2017, p. 95).

Berdasarkan rekapitulasi pengumpulan tugas pada proses pembelajaran asynchronous learning kelas XI Akuntansi diketahui bahwa motivasi belajar peserta didik berada pada kategori rendah. Hal tersebut terlihat dari banyaknya jumlah peserta didik yang tidak tepat waktu dalam mengumpulkan tugas. Kurangnya motivasi belajar peserta didik tersebut dapat dilihat dari 7 peserta didik $(21,87 \%)$ dari kelas XI AK 1, 17 peserta didik (51,51\%) dari kelas 
XI AK 2, 19 peserta didik $(55,88 \%)$ dari kelas XI AK 3, 21 peserta didik (63,64\%) dari kelas XI AK 4, dan 23 peserta didik $(71,87 \%)$ dari kelas XI AK 5 terlambat dalam mengumpulkan tugas harian.

Setelah mengetahui kendala hasil belajar, pihak Sekolah merancang dan menyiapkan pembelajaran e-learning dengan lebih matang lagi. Dengan penyiapan ini diharapkan bahwa di semester depan atau semester pertama pada kelas XII, penerapan asynchronous learning akan membawa hasil yang lebih baik sehingga bisa berdampak pada motivasi belajar peserta didik. Dengan penerapan asynchronous learning yang lebih baik dan diiringi dengan motivasi belajar yang tinngi maka hasil belajar peserta didik khususnya pada mata pelajaran Administrasi Pajak juga meningkat.

\section{METODE}

Jenis penelitian ini menggunakan pendekatan kuantitatif dengan jenis penelitian ex-post facto. Penelitian jenis ex-post facto merupakan penelitian tentang variabel yang kejadiannya sudah terjadi pada penelitian dilaksanakan dan kemudian merunut ke belakang untuk mengetahui faktor-faktor yang menyebabkan timbulnya kejadian tersebut (Arikunto, 2013, p. 17).

Penelitian ini dilaksanakan di SMK YPKK 2 Sleman, dengan populasi dalam penelitian ini adalah seluruh siswa kelas XII Jurusan Akuntansi Keuangan dan Lembaga di SMK YPKK 2 Sleman dengan jumlah 162 peserta didik dan jumlah sampel yang diambil sebanyak 64 Peserta didik. Teknik pengumpulan data dalam penelitian ini menggunakan angket dan dokumentasi. Angket digunakan untuk memperoleh data mengenai penerapan asynchronous learning dan motivasi belajar. Dokumentasi digunakan untuk memperoleh data mengenai hasil belajar Administrasi
Pajak dan rekapitulasi keterlambatan pengumpulan tugas.

Instrumen penelitian merupakan suatu alat yang digunakan untuk mengukur suatu fenomena alam maupun sosial yang diamati (Sugiyono, 2016, p. 148). Penelitian menggunakan angket tertutup untuk mempermudah peneliti mengumpulkan data agar lebih lengkap dan sistematis. Angket digunakan untuk memperoleh data langsung dari responden mengenai variabel penerapan asynchronous learning dan motivasi belajar.

Untuk mengetahui pengaruh masingmasing variabel bebas terhadap variabel terkait, peneliti membuat tiga hipotesis, ketiga hipotesis tersebut adalah hipotesis pertama berbunyi "Terdapat hubungan positif dan siginifikan antara penerapan asynchronous learning terhadap hasil belajar Administrasi Pajak"; hipotesis kedua berbunyi "Terdapat hubungan positif dan siginifikan antara motivasi belajar terhadap hasil belajar Administrasi Pajak"; dan hipotesis yang ketiga berbunyi "Terdapat hubungan positif dan siginifikan antara penerapan asynchronous learning dan motivasi belajar secara bersama-sama terhadap hasil belajar Administrasi Pajak".

Uji prasyarat analisis meliputi uji normalitas, uji linearitas, uji multikolinearitas, dan uji heterokedastisitas. Teknik analisis data yang digunakan dalam penelitian ini adalah analisis regresi sederhana dan analisis regresi ganda.

\section{HASIL PENELITIAN DAN PEMIBAHASAN}

Dengan diterapkannya pembelajaran pada masa darurat Covid-19, berbagai sektor di Indonesia mengalami perubahan yang signifikan. Berbagai lembaga baik pemerintah maupun swasta dituntut untuk beradaptasi dan mempersiapkan diri secepat mungkin di tengah krisis akibat pandemi. Untuk dapat bertahan diperlukan 
kemampuan manusia untuk berpikir kreatif dan inovatif dalam memecahkan masalah. Hal ini sejalan dengan penelitian Farah et al. (2018) yang menyatakan bahwa dalam rangka menyongsong masa depan diperlukan kemampuan di antaranya kemampuan inovasi dan berpikir kreatif.

Salah satu sektor yang mengalami perubahan yang sangat signifikan adalah sektor pendidikan. Peserta didik dan guru tidak bisa menyelenggarakan proses pembelajaran di sekolah karena pembelajaran dilaksanakan secara daring. Dengan penerapan pembelajaran daring banyak hal menjadi berubah. Perubahan ini terasa secara mendasar mulai dari administrasi pembelajaran hingga ke hasil belajar yang diperoleh oleh masing masing peserta didik. Setelah mengadakan berbagai persiapan, SMK YPKK 2 Sleman berhasil meningkatkan hasil belajar peserta didiknya di kelas XII pada mata pelajaran Administrasi Pajak.

Berdasarkan analisis data distribusi frekuensi. Kriteria Belajar Minimum (KBM) seorang peserta didik dinyatakan lulus apabila hasil belajarnya lebih dari atau sama dengan 75 , begitu pula sebaliknya. Hasil analisis statistik data penerapan asynchronous learnng diperoleh skor tertinggi sebesar 95; skor terendah sebesar 55 ; dengan nilai Mean $(M)$ sebesar 78,05; Median ( $\mathrm{Me}$ ) sebesar 78,00; Modus (Mo) sebesar 77; dan Standar Deviasi (SD) sebesar 6,936. Berdasarkan analisis data hasil belajar Administrasi Pajak pada Tabel 1, dapat dilihat bahwa mayoritas peserta didik termasuk ke dalam kategori lulus sedangkan 18 peserta didik gagal.

Peningkatan jumlah peserta didik yang berada pada kategori lulus ini tidak lepas dari pengaruh penerapan asynchronous learning yang lebih efektif serta pengaruh motivasi belajar peserta didik yang menjadi lebih tinggi. Setelah data mengenai hasil belajar berhasil dianalisis, peneliti melanjutkan proses selanjutnya untuk menganalisis data tentang asynchronous learning.

Tabel 1

Kecenderungan Hasil Belajar Administrasi Pajak

\begin{tabular}{ccc}
\hline Skor & Frequensi & Kategori \\
\hline$\leq 75$ & 18 & Gagal \\
$\geq 76$ & 46 & Tuntas \\
\hline Total & 64 & \\
\hline
\end{tabular}

Data mengenai penerapan asynchronous learning bisa lihat pada Tabel 2 yang menunjukkan frekuensi kecenderungan penerapan asynchronous learning. Data tersebut diperoleh melalui angket tertutup yang diberikan kepada peserta didik kelas XII. Angket ini digunakan untuk menilai sejauh mana pengaruh penerapan asynchronous learning. Hasil analisis data dalam Tabel 2 menunjukkan bahwa peserta didik menilai penerapan asynchronous learning membawa pengaruh terhadap hasil belajar Administrasi Pajak sangat tinggi

Tabel 2

Kategori Kecenderungan Penerapan Asynchronous Learning

\begin{tabular}{cccc}
\hline Interval & Freq & $\%$ & Kategori \\
\hline $\mathrm{X} \geq 54$ & 30 & 46,88 & Sangat Tinggi \\
$45 \leq \mathrm{X}<54$ & 26 & 40,63 & Tinggi \\
$36 \leq \mathrm{X}<45$ & 7 & 10,94 & Rendah \\
$\mathrm{X}<36$ & 1 & 1,56 & Sangat Rendah \\
\hline Total & 64 & 100 &
\end{tabular}


46,88\%; tinggi 40,63\%; rendah $10,94 \%$; dan $1,56 \%$ sangat rendah.

Selain pemilihan model pembelajaran yang tepat, dalam pembelajaran di masa pandemi, guru juga perlu mempertimbangkan aspek motivasi belajar. Motivasi belajar berguna untuk memicu semangat yang dimiliki oleh peserta didik. Dengan adanya motivasi belajar yang tinggi seorang peserta didik akan menjadi lebih giat dan rajin dalam melaksanakan pembelajaran sehingga hasil belajar merekapun cenderung lebih baik ketimbang peserta didik lain yang mempunyai motivasi belajar rendah.

Penerapan model pembelajaran yang tepat akan mengakibatkan motivasi belajar peserta didik terjaga. Oleh karena itu, apapun yang diterapkan oleh guru dalam pembelajaran, hendaknya memperhatikan aspek motivasi belajar para peserta didik.

Keberadaan motivasi dalam diri peserta didik berbeda-beda antara satu dengan yang lainnya. Hal inilah yang menjadikan keragaman aktivitas belajar peserta didik dalam proses pembelajaran. Rahmawati (2016, p. 332) faktor yang mempengaruhi motivasi belajar peserta didik yaitu peran guru, ketertarikan terhadap materi, lingkungan teman, cita-cita atau aspirasi, dan kondisi siswa. Lebih lanjut, Siregar dan Nara (2014, pp. 53-54) menyatakan terdapat enam unsur yang menjadi faktor motivasi belajar peserta didik yang meliputi cita-cita/ aspirasi, kemampuan pembelajar, kondisi pembelajar, kondisi lingkungan pembelajar, unsur-unsur dinamis belajar/ pembelajaran, dan upaya guru dalam membelajarkan.

Cita-cita merupakan harapan tertinggi peserta didik yang mereka ingin capai. Faktor "ingin menjadi apa" di masa depan menjadi sebuah faktor yang sangat penting karena peserta didik akan semakin terpacu semangatnya apabila disangkutpautkan dengan masa depannya. Selanjutnya, dalam belajar siswa mempunyai batasan tersendiri. Batasan ini timbul karena kemampuan peserta didik berbeda-beda sehingga menyebabkan batasan yang berbeda. Oleh karena itu, penting bagi setiap peserta didik untuk mengetahui kemampuan yang ingin dikuasai karena tidak semua peserta didik termotivasi pada bidang yang sama.

Untuk mengetahui kondisi motivasi belajar peserta didik, peneliti mengumpulkan data motivasi belajar peserta didik melalui instrumen tertutup yang dapat dilihat pada Tabel 3. Berdasarkan analisis data pada Tabel 3, diperoleh informasi bahwa motivasi belajar peserta didik berada pada kategori sangat tinggi 45,32\%; tinggi 42\%; rendah $0 \%$; dan sangat rendah $12,5 \%$ yang menandakan bahwa mayoritas peserta didik mempunyai motivasi belajar tingggi.

Setelah semua data terkumpul, peneliti melakukan uji prasyarat analisis pada setiap variabel. Uji prasyarat analisis yang digunakan dalam penelitian ini ada empat yakni uji normalitas, linearitas,

Tabel 3

Kategori Kecenderungan Motivasi Belajar

\begin{tabular}{lccc}
\hline \multicolumn{1}{c}{ Interval } & Freq & $\%$ & Kategori \\
\hline $\mathrm{X} \geq 54$ & 29 & 45,32 & Sangat Tinggi \\
$45 \leq \mathrm{X}<54$ & 27 & 42,18 & Tinggi \\
$36 \leq \mathrm{X}<45$ & 0 & $0 \%$ & Rendah \\
$\mathrm{X}<36$ & 8 & 12,50 & Sangat Rendah \\
\hline \multicolumn{1}{c}{ Total } & 64 & 100 & \\
\hline
\end{tabular}


multikolinearitas, dan heterokedastisitas. Apabila data bisa melewati ke-4 uji prasyarat analisis maka uji hipotesis dapat dilakukan.

Hasil uji normalitas menunjukkan nilai Asym.Sig. $>$ A $(0,200>0,05)$ yang berarti seluruh data variabel pada penelitian ini berdistribusi normal. Uji linearitas yang dilakukan menunjukkan $F_{\text {hitung }} \leq F_{\text {Tabel }}$ Dapat disimpulkan bahwa data penerapan asynchronous learnig, motivasi belar dan hasil belajar Administrasi Pajak memiliki hubungan yang linier.

Berdasarkan hasil uji multikolinearitas dapat diketahui jika koefisien korelasi antarvariabel bebas lebih kecil dari 0,70; maka tidak terjadi multikolinearitas antarvariabel bebas sehingga uji regresi dapat dilanjutkan. Hasil uji heterokodestisitas menunjukkan Sig.> 0,05; maka tidak terjadi heteroskedastisitas.

Hipotesis pertama yang diuji adalah "Terdapat pengaruh positif dan signifikan antara penerapan asynchronous learning terhadap hasil belajar administrasi pajak". Berdasarkan hasil uji regresi, didapati nilai koefisien korelasi $\left(r_{x l y}\right)$ lebih besar dari nol $(0)$ yaitu sebesar 0,247 yang menunjukkan bahwa Penerapan asynchronous learning memiliki hubungan positif terhadap hasil belajar Administrasi Pajak. Selain itu, nilai koefisien determinasi $\left(r_{x l y}^{2}\right)$ menunjukkan nilai sebesar 0,061 . Dengan hasil ini dapat disimpulkan terdapat pengaruh positif dan signifikan antara penerapan asynchronous learning terhadap hasil belajar Administrasi Pajak.

Hasil uji hipotesis pertama ini selaras dengan penelitian yang dilakukan oleh Mulyani (2013). Penelitian tersebut melakukan perbandingan antara pembelajaran konvensional dengan pembelajaran e-learning. Hasilnya menunjukkan bahwa tidak ada pengaruh yang positif dan signifikan antara pembelajaran konvensional dengan hasil belajar peserta didik. Sebaliknya, pembelajaran dengan e-learning mempunyai pengaruh positif dan signifikan terhadap hasil belajar peserta didik. Penelitian ini juga diperkuat oleh Rani (2014) yang menyatakan bahwa "internet terbukti berpengaruh dan efektif untuk meningkatkam hasil belajar siswa".

Dengan diketahuinya penerapan asynchronous learning membawa dampak yang positif bagi hasil belajar peserta didik, sebaiknya cara ini dipertahankan kualitasnya agar mengarah kepada pembelajaran yang memberi manfaat dan memberikan ilmu pengetahuan yang seutuhnya bukan hanya mencari nilai. Hal ini tentu memerlukan peran dari pihak guru dan juga peserta didik. Dari segi guru, pembuatan media pembelajaran yang menarik dan mudah dipahami menjadi salah satu kunci dalam keberhasilan pembelajaran. Media pembelajaran yang menarik adalah media yang tidak monoton dan membosankan seperti hanya memberikan peserta didik teks bacaan yang harus mereka baca dan pahami. Hal ini bisa diberikan sentuhan inovasi berupa pembuatan video penjelasan atau membuat teks monoton tadi menjadi teks yang disertai gambar dan tulisannya dibuat menarik. Media yang mudah dipahami adalah media yang bisa dijalankan oleh semua peserta didik serta isinya mudah dimengerti. Dari banyaknya media yang ada, media yang memenuhi kriteria tersebut dan mudah dibuat oleh guru adalah video yang dilengkapi teks penjelasan.

Bagi pesesrta didik agar pembelajaran asynchronous learning bisa berjalan lancar mereka perlu "hadir" tepat waktu dan juga membaca instruksi yang diberikan sebelum pembelajaran dimulai. Ketepatan waktu saat belajar online merupakan salah satu aspek yang sangat penting karena sudah banyak platform yang menyediakan deadline pengumpulan tugas. Selain itu, peserta didik juga perlu membaca dan memahami 
tata cara pembelajaran yang telah diberikan oleh guru agar tidak terjadi kebingungan saat pembelajaran atau pengerjaan tugas.

Hipotesis kedua yang diuji adalah "Terdapat pengaruh positif dan signifikan antara motivasi belajar terhadap hasil belajar Administrasi Pajak". Berdasarkan hasil uji regresi, didapati nilai koefisien korelasi $\left(r_{x 2 y}\right)$ lebih besar dari nol (0) yaitu sebesar 0,274 yang berarti bahwa motivasi belajar mempunyai hubungan positif terhadap hasil belajar Administrasi Pajak. Selain itu, nilai koefisien determinasi $\left(r_{x-2 y}^{2}\right)$ mempunyai nilai lebih besar dari 0 yakni sebesar 0,075. Dengan hasil ini maka dapat diartikan bahwa terdapat pengaruh positif dan signifikan antara motivasi belajar terhadap hasil belajar Administrasi Pajak.

Hasil penelitian ini selaras dengan penelitian yang dilakukan oleh Widiarti (2018) yang menunjukkan hasil bahwa terdapat pengaruh positif dan signifikan Motivasi Belajar terhadap hasil belajar mata pela-jaran ekonomi siswa kelas $\mathrm{X}$ ilmuilmu sosial di SMA Negeri 2 Banguntapan dengan nilai koefisien regresi sebessar 0,6-63 pada taraf signifikansi 5\%. Dapat diketahui $t_{\text {hitung }}$ sebesar 9,984 dengan nilai signifikansi 0,00-0. Selain itu, penelitian dari Supina (2013) memperkuat hasil penelitian ini. Dalam penelitian tersebut diperoleh hasil bahwa motivasi belajar berpengaruh secara positif dan signigfikan terhadap hasil belajar peserta didik.

Hasil penelitian ini juga didukung oleh Dimyati dan Mudjiono (2009) yang menyatakan bahwa salah satu faktor intern yang mempengaruhi prestasi belajar akuntansi adalah motivasi belajar. Motivasi belajar merupakan kekuatan mental yang mendorong terjadinya proses belajar. Sudjana (2010, pp. 39-40) mengungkapkan bahwa faktor yang datang dari dalam diri siswa besar sekali pengaruhnya terhadap hasil belajar yang dicapai.
Dengan hasil penelitian yang menunjukkan bahwa motivasi belajar membawa dampak yang positif bagi hasil belajar peserta didik berarti semakin tinggi motivas belajar, akan semakin tinggi pula hasil belajarnya. Akan tetapi, motivasi belajar yang dimiliki oleh peserta didik tidak selamanya tinggi dan mengarah ke hal yang positif. Adakalanya motivasi belajar peserta didik menjadi drop dan menyebabkan mereka menjadi tidak bersemangat dalam mengikuti pembelajaran. Oleh karena itu, agar motivasivas belajar peserta didik terjaga kearah yang positif diperlukan langkahlangkah yang diambil oleh pihak sekolah, keluarga, dan peserta didik. Bagi pihak sekolah langkah yang perlu diambil adalah memberikan penyuluhan pelaksanaan pembelajaran online kepada orang tua/wali peserta didik. Hal tersebut perlu dilakukan mengingat masih banyak orangtua yang belum mengetahui tentang belajar online. Penyuluhan dilakukan agar para orangtua/ wali bisa menjaga kondisi di rumahnya tetap kondusif untuk melaksanakan pembelajaran online. Pembelajaran yang dilakukan pada kondisi yang kondusif diharapkan menjaga motivasi dan pikiran peserta didik agar fokus dalam mengikuti pembelajaran.

Hal ini tentunya juga harus mendapatkan follow up yang baik dari orangtua agar yang disampaikan dalam penyuluhan bisa diterapkan. Mereka bisa mengingatkan anak-anaknya untuk mengerjakan tugas tepat waktu, membantu mempersiapkan alat-alat yang diperlukan selama pembelajaran online berlangsung, dan juga mengkondisikan lingkungan sekitar rumah agar tidak mengganggu. Bagi peserta didik, menjaga motivasi merupakan hal yang bisa mereka dapat dengan memahami pentingnya belajar Administrasi Pajak seperti mengetahui pekerjaan yang akan ia peroleh setelah mereka bisa mahir dan menguasai materi 
pajak. Hal ini membutuhkan kesadaran yang tinggi dari peserta didik itu sendiri.

Hipotesis ketiga yang diuji adalah "Terdapat pengaruh positif dan signifikan antara penerapan asynchronous learning dan motivasi belajar terhadap terhadap hasil belajar Administrasi Pajak". Berdasarkan hasil uji regresi ganda, didapati nilai nilai koefisien korelasi $\left(r_{y(1,2)}\right)$ lebih besar dari nol (0) yaitu sebesar 0,344. Nilai koefisien determinasi $\left(r_{y(1,2)}^{2}\right)$ menunjukkan hasil yang lebih besar dari 0 yakni sebesar 0,119 yang berarti terdapat pengaruh positif dan signifikan antarvariabel yang diuji. Dengan hasil ini, dapat disimpulkan bahawa terdapat pengaruh positif dan signifikan antara penerapan asynchronous learning dan motivasi belajar terhadap hasil belajar Administrasi Pajak.

Hasil penelitian ini selaras dengan penelitian yang dilakukan oleh Sindu dkk. (2013) hasilnya menunjukkan bahwa terdapat pengaruh interaktif yang signifikan antara model pembelajaran e-learning dan motivasi belajar. Model e-learning yang baik akan memicu motivasi belajar pesera didik menjadi lebih tinggi. Dengan tingginya motivasi belajar peserta didik, akan diiringi pula dengan kenaikan hasil belajarnya. Selain itu, pada penelitian Fadilah (2014) juga memperoleh hasil yang sama. Disebutkan bahwa penggunaan e-learning dan motivasi belajar secara bersama berpengaruh terhadap hasil belajar peserta didik. Teori yang dikemukakan oleh Fadilah (2014) yang menyatakan bahwa saat ini e-learning moodle adalah sebuah media yang tepat karena dapat membuat siswa menjadi lebih termotivasi. Teori tersebut menunjukkan bahwa penggunaan e-learning dapat meningkatkan motivasi belajar. Dampak dari meningkatnya motivasi belajar ini adalah adanya peningkatan semangat dalam melaksanakan kegiatan pembelajaran (Ferismayanti, 2019). Efek dari semakin tingginya motivasi belajar adalan peningkatan hasil belajar.

Berdasarkan hasil analisis regresi ganda, dapat diketahui besarnya Sumbangan Relatif (SR) dan Sumbangan Efektif (SE) pada masing-masing variabel bebas (X1dan X2) terhadap variabel terikat (Y). Berdasarkan pengolahan data dapat diketahui Sumbangan Relatif (SR\%). Masing-masing variabel bebas yaitu penerapan asynchronous learning (X1) sebesar 43,9\% dan motivasi belajar (X2) sebesar 56,1\%. Sumbangan Efektif (SE\%) pada masing-masing variabel bebas yaitu penerapan asynchronous learning (X1) sebesar 5,2\% dan motivasi belajar (X2) sebesar 6,7\%. Jumlah SE keseluruhan sebesar $11,7 \%$.

Dengan terbuktinya penerapan asynchronous learning dan motivasi belajar secara bersama-sama membawa dampak yang positif bagi hasil belajar peserta didik. Diperlukan langkah strategis untuk tetap mempertahankan dan mengembangkan metode belajar yang baru ini. Di masa depan, dunia akan menjadi lebih digital dan begitu pula dengan dunia pendidikan. Sistem, prosedur, dan materi yang sudah dikembangkan selama pandemi ini harus tetap dijaga keberadaannya dan juga dikembangkan sebaik mungkin oleh guru. Materi yang tersebar di berbagai platform dan media belajar hendaknya dijadikan guru sebagai tambahan materi belajar bagi siswa ketimbang membuang dan menjadikan segala sesuatunya seperti semula apabila kondisi sudah normal.

\section{SIMPULAN}

Terdapat pengaruh positif dan signifikan penerapan asynchronous learning terhadap hasil belajar Administrasi Pajak peserta didik. Terdapat pengaruh positif dan signifikan motivasi belajar administrsai pajak terhadap hasil belajar Administrasi Pajak. Terdapat pengaruh positif dan 
signifikan penerapan asynchronous learning dan motivasi belajar terhadap hasil belajar Administrasi Pajak.

\section{DAFTAR PUSTAKA}

Alpian, Y., Anggraeni, S. W., Wiharti. U., \& Soleha, N. M. (2019). Pentingnya pendidikan bagi manusia. Jurnal Buana Pengabdian, 1(1), 66-72. https://journal.ubpkarawang.ac.id/ index.php/JurnalBuanaPengabdian/ article/view/581/537.

Arikunto, S. (2013). Prosedur penelitian suatu pendekatan praktik. Rineka Cipta.

Dimyati dan Mudjiono. (2009). Belajar dan pembelajaran. Rineka Cipta

Emda, A. (2017). Kedudukan motivasi belajar siswa dalam pembelajaran. Lantanida Journal. 5(2), 93-196. https://jurnal.araniry.ac.id/index.php/ lantanida/article/view/2838/2064.

Fadilah, A. I., Munoto, \& Nurlaela, L. (2014). Pengaruh media pembelajaran (E-learning moodle, LKS) dan motivasi terhadap hasil belajar pengoperasian perangkat lunak lembar sebar di SMKN 1 Mojokerto. Jurnal Pendidikan Vokasi: Teori dan Praktek, 2(1). 12-19. https:// jurnalmahasiswa.unesa.ac.id/index. $\mathrm{php} /$ pendidikan-avokasi-teori-danprak/article/view/8696.

Falah, A. (2015). Studi analisis aspek-aspek keberhasilan pembelajaran pendidikan agama Islam di SDN 1 Karangmalang Gebog Kudus. Elementary, 3(1), 171-195. https://journal.iainkudus. ac.id/index.php/elementary/article/ view/1449/1325.

Farah, R. N., Tarmizee, M., Abd Rahman, K., \& Zuraida, R. L. (2018). Orthogonal Projector Kit (OPK) as a new teaching aids with innovation ICT in teaching and learning $21^{\text {st }}$ Century. Journal of Fundamental and Applied Sciences, 10(3S), 338-344.
Fauziyah, S., \& Triyono, M. B. (2020). Pengaruh e-learning edmodo dengan model blended learning terhadap minat belajar. Jurnal kependidikan, 4(01), 112-124. https://journal.-uny.ac.id/ index.php/jk/article/view/27562/pdf.

Ferismayanti. (2020, 20 Mei). Meningkatkan motivasi belajar siswa pada pembelajaran online akibat pandemi Covid-19. https://lpmplampung. kemdikbud.go.id/.

Peraturan Menteri Pendidikan dan Kebudayaan Republik Indonesia Nomor 23 Tahun 2016 tentang Standar Penilaian Pendidikan.

Surat Edaran Nomor 4 Tahun 2020 tentang Pelaksanaan Kebijakan Pendidikan dalam Masa Darurat Penyebaran Corona Virus Diseas (Covid-19).

Kunandar. (2014). Penilaian autentik (Penilaian hasil belajar peserta didik berdarsarkan Kurikulum 2013). Raja Grafindo Persada.

Kurniawan, B., Wihara, O. \& Permana, T. (2017). Studi analisis faktor-faktor yang mempengaruhi hasil belajar pada mata pelajaran teknik listrik dasar otomotif. Journal of Mechanical Engineering Education, 4(2), 156-162. https://ejournal.upi.edu/index.php/ jmee/article/view/9627.

Peraturan Pemerintah Nomor 19 Tahun 2005 tentang Standar Pendidikan Nasional.

Muchlis, M., Fahmi, I., \& Krisanti, M. (2018). Strategi peningkatan penerapan metode pembelajaran e-learning pada program sarjana. Jurnal kependidikan, 2(1), 141-152. https://journal.uny. ac.id/in-dex.hp/jk/article/view/9578.

Mulyani. (2013). Pengaruh pembelajaran berbasis e-learning terhadap hasil belajar siswa pada konsep impuls dan momentum (Skripsi tidak diterbitkan). UIN Syarifhidayatullah, Jakarta. 
Pakpahan, R., \& Fitriani, Y. Analisa pemanfatan teknologi informasi dalam pembelajaran jarak jauh di tengah pandemi virus corona Covid-19. JISAMAR (Journal of Information System, Applied, Management, Accounting, and Research), 4(02), 3036. http://journal.stmi-kjayakarta.ac.id/ index.php/jisamar/article/view/181.

Sindu, I. G. P., Santyasa, I. W., \& Warpala, I. W. S. (2013). Pengaruh model e-learning berbasis masalah dan motivasi belajar terhadap hasil belajar KKPI siswa kelas $X$ di SMK Negeri 2 Singaraja. Jurnal Teknologi Pembelajaran Indonesia, 3(1).

Siregar, E., \& Nara, H. (2010). Teori belajar dan pembelajaran. Ghalia Indonesia.

Sudjana, N. (2013). Penilaian hasil proses belajar mengajar. PT Remaja Rosdakarya.
Sugiyono.(2010). Metode penelitian pendidikan. Alfabeta.

Supina. (2013). Pengaruh motivasi terhadap hasil belajar siswa kelas XC pada mata pelajaran ekonomi di SMA (Skripsi tidak diterbitkan). Universitas Tanjungpura, Pontianak. https://jurnal. untan.ac.id/index.php/jpdpb/article/ view/3330.

Suprihatin, S. (2015). Upaya guru dalam meningkatkan motivasi belajar siswa. Jurnal Pendidikan Ekonomi UM Metro, 3(1), 73-82.

Tiurma, L., \& Retnawati, H. (2014). Keefektifan pembelajaran multimedia materi dimensi tiga ditinjau dari prestasi dan minat belajar matematika di SMA. Jurnal Kependidikan: Penelitian Inovasi Pembelajaran, 44(2). 